\title{
Experimental Study of Adobe Masonry and its Adherence with Reinforced Concrete Confinement Elements
}

\author{
Jesús A. Velarde Gil L. ${ }^{1}$, María T. Sánchez M. ${ }^{2, *}$, Rubén S. Roux G. ${ }^{3}$, José A. Espuna M. ${ }^{2}$ \\ ${ }^{1}$ Department of Earth Sciences, Technological Institute of Tijuana, Baja California, México \\ ${ }^{2}$ Faculty of Architecture, Design, and Urbanism, University Autonomous of Tamaulipas, Circuito Universitario S/N, Centro \\ Universitario Sur, Tampico, Tamaulipas, México \\ ${ }^{3}$ Tamaulipas Institute of Higher Studies, IEST-ANÁHUAC, Altamira, Tamaulipas, México
}

Received December 3, 2020; Revised February 18, 2021; Accepted March 12, 2021

\section{Cite This Paper in the following Citation Styles}

(a): [1] Jesús A. Velarde Gil L., María T. Sánchez M., Rubén S. Roux G., José A. Espuna M. , "Experimental Study of Adobe Masonry and its Adherence with Reinforced Concrete Confinement Elements, "Civil Engineering and Architecture, Vol. 9, No. 2, pp. 404-409, 2021. DOI: 10.13189/cea.2021.090213.

(b): Jesús A. Velarde Gil L., María T. Sánchez M., Rubén S. Roux G., José A. Espuna M. (2021). Experimental Study of Adobe Masonry and its Adherence with Reinforced Concrete Confinement Elements. Civil Engineering and Architecture, 9(2), 404-409. DOI: 10.13189/cea.2021.090213.

Copyright $(2021$ by authors, all rights reserved. Authors agree that this article remains permanently open access under the terms of the Creative Commons Attribution License 4.0 International License

\begin{abstract}
The constructions with adobe masonry confined with concrete elements, experience a separation between them, mainly due to the inherent physical and chemical characteristics of both materials that are not very compatible with each other; adobe, a raw masonry with a high clay content, undergoes changes in its shape in the presence of humidity and temperature variation, which affects its adherence to concrete elements, compromising the confinement, function and stability of the walls. The different coefficients of expansion and contraction between concrete and adobe, added to their physical properties, make it difficult to achieve adequate adherence between these two materials. In the present study, 6 mixtures of earth (adobe) were designed, with different granulometry proportions to measure the adherence between adobe and concrete, identifying the most suitable one with the purpose of using it as a bonding material in walls for houses, from this study, with the best response being the sample MA-3. The test methodology was based on standards applicable to concrete and annealed brick masonry, as there is no available one for this material. Thirty-six adobe specimens adhered to concrete were tested, to which a normal load was gradually applied to their cross section, to a piece of adobe between two pieces of concrete, recording the ultimate horizontal shear stress between both materials. The scope is considered the result
\end{abstract}

of the test of adobe pieces adhered to concrete subjected to horizontal shear force, considering different granulometry in the composition of the adobe mixture. This work provides a starting point for the standardization of the test and the justification of the need for an additional element that contributes to the confinement.

Keywords Adobe, Adherence, Concrete, Confined

\section{Introduction}

The confined masonry arises from the need for perimeter reinforcement with reinforced concrete elements that guarantee the monolithic behavior between both structural materials [1]; the concept of confinement is based on the positive results that have been observed in annealed mud brick constructions, forming boards that provide deformation capacity much greater than that of unconfined walls [2].

The material most used in rural housing walls in Latin America is adobe, but the vulnerability of these systems to the presence of a seismic event, and the lack of rigidity of their walls, as well as their bond with the roof, has led to the adobe masonry proposal with confinement based on 
concrete elements, seeking to improve this weakness in stability; the lack of that confinement in the walls or elements that guarantee a union between them causes the existence of different modes of failure: by bending in the plane and outside it [3], compression, flexo-compression [4], shear stress, failure in wall joints, roof wall joint [5].

In the union of adobe with concrete, there is an adherence problem after these materials are in a dry state, which causes a separation between them, and hinders the optimal work so that the wall works as a rigid diaphragm, considering that they are two materials with poor compatibility, different chemical composition and manufacturing process, in addition to possessing different physical properties such as shrinkage, compressive strength, modulus of elasticity and consequently rigidity of the structural element.

Adherence is one of the most important physical properties in hardened glue mortars with variable and unpredictable responses, with aspects that have to be addressed such as resistance, adherence degree and durability [6]; these same standards refer to others that must be followed to measure adherence, but that does not relate this for concrete with adobe, there are few studies in this regard, being able to take as a reference experiment carried out with mud mortar in union of adobe pieces with an average shear stress of $0.038 \mathrm{Mpa}$ [7]; or in the union of cement blocks with cement-sand mortar [8].

Even so, [1], mentions that the masonry-confinement tie-column connection can be toothed or flush, providing horizontal steel elements embedded in the mortar joint and anchoring inside the tie-column.

This work specifically seeks to establish parameters for the measurement of that adherence between the adobe and the confinement element without considering any type of additional reinforcement; identifying the one with the best physical and mechanical behavior out of $6 \mathrm{mix}$ designs with different granulometries.

\section{Methodology}

The methodological work was resolved in three phases: first, the determination the physical properties of the material used and the design of the mixture; second, through the manufacture of adobe pieces, as well as the construction of joined adobe-concrete composite specimens; third, the process for the adherence test for the different specimens.

\subsection{Physical Properties and Design of the Mixture}

For the preparation of adobe, special care must be taken, that the soil does not contain a high content of clay, due to its high drying shrinkage. As a reference, the Peruvian Standard E.080 [9], section 4.1 has been used suggests the following gradation: sand in a range of $55 \%$ to $70 \%$, silt between $15 \%$ and $25 \%$ and clay between $10 \%$ and $20 \%$, not being due use organic soils. Being able to vary when the adobes are stabilized to improve some of their properties, generally their behavior in the presence of humid areas.

The source of land for the manufacture of adobe comes from the Otay area, Tijuana, Mexico, specifically in the area occupied by the Technological Institute of Tijuana, which is characterized by its content of inorganic clays of medium plasticity, with fine-grained dark brown colored sands, (CL classification SUCS), the sand comes from the Abelardo L. Rodríguez dam's sandbar in the same city; 6 mixtures (M) were designed with different granulometry, in order to manufacture 6 adobe specimens for each design, Table 1.

Table 1. Proportion in volume

\begin{tabular}{|c|c|c|c|c|c|c|}
\hline Mix design & M-1 & M-2 & M-3 & M-4 & M-5 & M-6 \\
\hline Soil (clay) & 1 & 1 & 1 & 1 & 1 & 1 \\
\hline Sand & 2 & 1 & 0.5 & 2 & 1 & 0.5 \\
\hline $\begin{array}{c}\text { Gravel (5-9 } \\
\text { mm) }\end{array}$ & 0 & 0 & 0 & 1 & 1 & 1.5 \\
\hline Straw & 0.1 & 0.1 & 0.1 & 0.1 & 0.1 & 0.1 \\
\hline Water (L) & 0.2 & 0.2 & 0.2 & 0.2 & 0.2 & 0.2 \\
\hline
\end{tabular}

For each mixing group, from M-1 to M-6, particle size, index property and changes in volume of the material, were determined according to the following standards, Table 2.

Table 2. Applied standards

\begin{tabular}{|c|c|}
\hline Text & Standard \\
\cline { 1 - 1 } Granulometry & ASTM D2487-17 [10] \\
\cline { 1 - 1 } Liquid \& plastic limit \% & NMX-C-493-ONNCCE-2018 [11] \\
\cline { 1 - 2 } Plasticy index \% & ASTM D427-04 [12] \\
\hline Shrinkage \% & NMX-C-522-ONNCCE-2016 [13] \\
\hline Expansion $\%$ & \\
\hline
\end{tabular}

\subsection{Manufacture of Adobe Pieces and Adobe-Concrete Elements}

\subsubsection{Universe}

Given the lack of norms on adobe construction in Mexico, for the selection of samples, the Peruvian Standard E.080 section 8.0 [9] was taken as a reference for the breaking forces, specifying a minimum of 6 test specimens; 36 pieces of adobe were manufactured, 6 of each type identified with the letter $\mathrm{A}$, followed by the mixture number, $25 \mathrm{~cm} \times 9 \mathrm{~cm} \times 30 \mathrm{~cm}$ as an average measurement, Table 3. 
Table 3. Adobe elements

\begin{tabular}{|c|c|c|c|c|c|}
\hline Specimen & Pieces & $\begin{array}{c}\text { Width } \\
\text { cm }\end{array}$ & $\begin{array}{c}\text { Length } \\
\text { cm }\end{array}$ & $\begin{array}{c}\text { Height } \\
\text { cm }\end{array}$ & $\begin{array}{c}\text { Area 2 } \\
\text { faces cm }\end{array}$ \\
\hline A-1 & 6 & 25.33 & 29.82 & 8.77 & 1516 \\
\hline A-2 & 6 & 25.00 & 29.50 & 8.72 & 1475 \\
\hline A-3 & 6 & 24.47 & 29.02 & 8.65 & 1420 \\
\hline A-4 & 6 & 25.28 & 29.80 & 8.52 & 1506 \\
\hline A-5 & 6 & 25.17 & 29.65 & 9.00 & 1490 \\
\hline A-6 & 6 & 25.03 & 29.60 & 8.77 & 1478 \\
\hline
\end{tabular}

At the same time, concrete elements were cast on the adobes to prepare the composite specimens (MA) for the adherence test, as indicated in Table 4.

Table 4. Concrete-adobe elements

\begin{tabular}{|c|c|c|}
\hline Specimen & Pieces & Area (2 faces)(m ${ }^{2}$ \\
\hline MA-1 & 6 & 1516 \\
\hline MA-2 & 6 & 1475 \\
\hline MA-3 & 6 & 1420 \\
\hline MA-4 & 6 & 1506 \\
\hline MA-5 & 6 & 1490 \\
\hline MA-6 & 6 & 1478 \\
\hline
\end{tabular}

Additionally, 6 cubes of $9 \mathrm{~cm} \times 9 \mathrm{~cm} \times 9 \mathrm{~cm}$ were built for each adobe mixture (CA) to carry out the direct compression test and have a parameter of resistance to compression of each of the pieces, Table 5 .

Table 5. Compressive test

\begin{tabular}{|c|c|c|c|c|c|}
\hline Specimen & Pieces & $\begin{array}{c}\text { Width } \\
\text { cm }\end{array}$ & $\begin{array}{c}\text { Length } \\
\text { cm }\end{array}$ & $\begin{array}{c}\text { Height } \\
\text { cm }\end{array}$ & $\begin{array}{c}\text { Area } \\
\mathbf{c m}^{2}\end{array}$ \\
\hline CA-1 & 6 & 9.31 & 9.55 & 9.05 & 88.86 \\
\hline CA-2 & 6 & 9.56 & 9.18 & 9.08 & 87.80 \\
\hline CA-3 & 6 & 8.96 & 8.65 & 9.12 & 77.42 \\
\hline CA-4 & 6 & 9.19 & 9.29 & 9.08 & 85.33 \\
\hline CA-5 & 6 & 9.15 & 9.08 & 9.02 & 83.04 \\
\hline CA-6 & 6 & 8.98 & 9.03 & 9.11 & 81.00 \\
\hline
\end{tabular}

\subsubsection{Design and Construction of Adobe Specimens}

The dimensions of the 6 adobe types, Figure 1A, are: $30 \mathrm{~cm}$ wide, $25 \mathrm{~cm}$ long and $9 \mathrm{~cm}$ high, as shown in Figure 1B, these dimensions obey to factors of ideal properties of thermal mass [14], structural support for the house rooms up to two levels, and manual handling of parts.
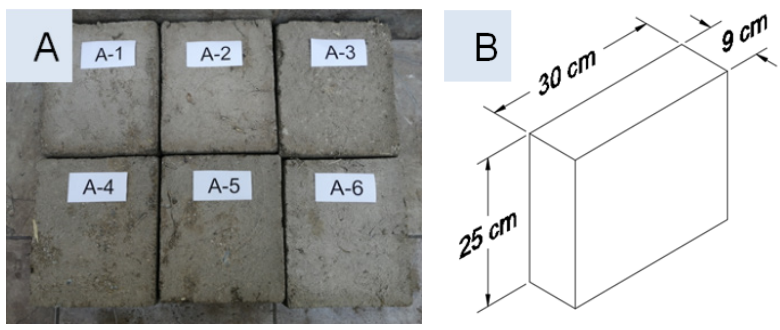

Source: authors.

Figure 1. (A) Different types of adobes. (B) Adobe dimensions
The manufacturing process consisted of pouring water into a basin, then alternately pouring earth, sand and straw, Figure 2A, mixing until obtaining a paste like composition, allowing it to stand for 24 to 48 hours. Depending on the weather conditions; manual molding was carried out on a flat surface, after 24 hours they were placed on their edges for drying, for a period of 30 days, Figure 2B.
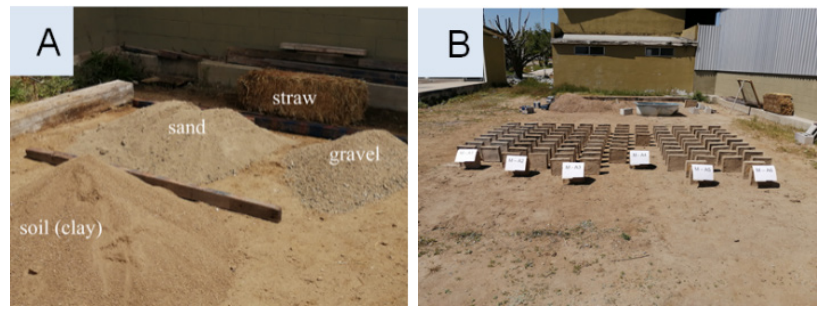

Source: authors.

Figure 2. (A) Materials. (B) Adobe drying

\subsubsection{Simple Adobe Specimens for Compression Test}

Before the adherence test, 6 adobe blocks of each mixture were tested, Figure $3 \mathrm{~A}, 9 \mathrm{~cm} \times 9 \mathrm{~cm} \times 9 \mathrm{~cm}$ according to standard NTE, E. 200-080 [9] to determine the resistance to direct compression, Figure 3B.
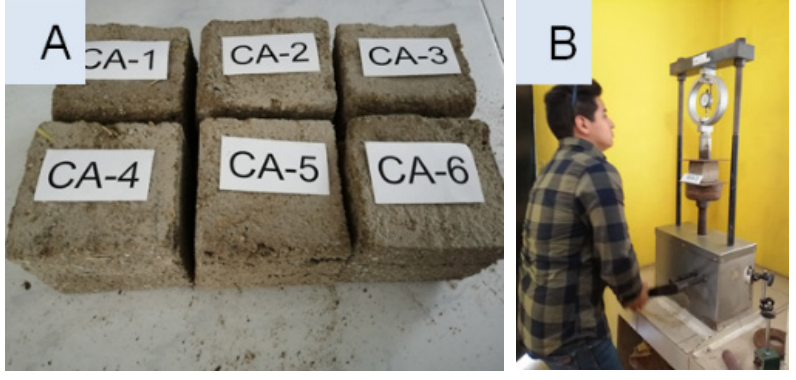

Figure 3. (A) Adobe cubes. (B) Compression test

\subsubsection{Combined Adobe-concrete Samples}

Six wooden molds of $30 \mathrm{~cm} \times 27 \mathrm{~cm} \times 25 \mathrm{~cm}$, Figure $4 \mathrm{~A}$, were prepared, with the intention of obtaining the specimen for the adherence test for the 6 groups of adobe samples, giving a total of 36 specimens for testing; first, a piece of adobe was placed in a vertical position (height 25 $\mathrm{cm}$ ) in the central part of the mold (side of $27 \mathrm{~cm}$ ).
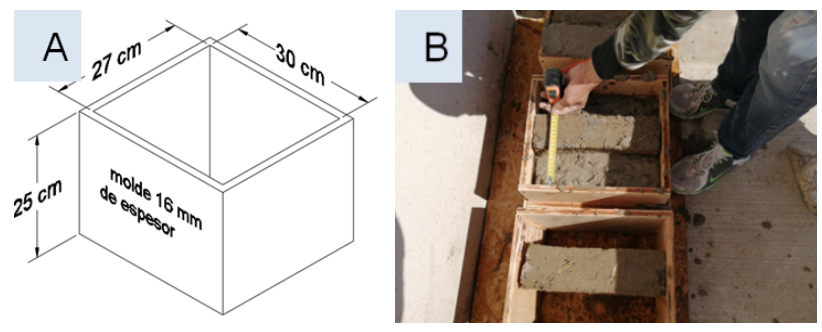

Figure 4. (A) Mold. (B) Concrete Pouring

The surface of the adobe is slightly moistened and concrete with $\mathrm{f}^{\prime} \mathrm{c}=150 \mathrm{~kg} / \mathrm{cm}^{2}$ begins to be poured into the mold, distributing it inside with the spoon, which is 
compacted by tamping 25 times uniformly with a $9 \mathrm{~mm}$ diameter rod, the mold is struck 16 times with a rubber mallet and the surface is leveled with the spoon or a spatula, Figure 4B. After 24 hours of casting, the specimens are removed from the mold, and curing with liquid paraffin compound is applied; they are stored for 28 days protected from the direct action of the sun's rays.

\subsection{Combined Specimen Adherence Testing Process}

The absence of a specific standard for this type of test with earth materials, led to the use of the British Standards Institution, BS EN 1052-3 (2002) [15] as a reference, which determines the initial horizontal shear stress for joint mortar, as it is the standard that most closely approximates the purpose of this study.

A hydraulic jack was used in a horizontal position with a load capacity of 20 tons, placing the test specimen in such a way that the central adobe piece was perpendicular to the stem of the jack, using a solid piece of wood as a force transmission element, solid $4 \mathrm{~cm}$ thick, which makes contact uniformly on the section of the adobe piece, Figure 5.

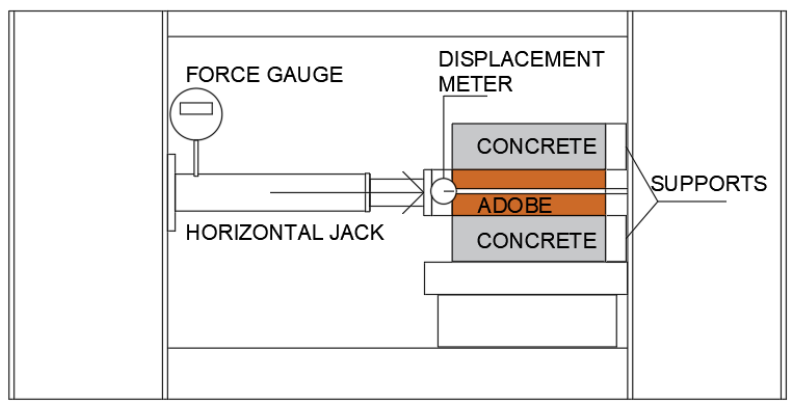

Figure 5. Hydraulic machine used for adherence test
Once the specimen has been correctly placed, the load is applied with a speed that varies between 0.8 to $1.0 \mathrm{MPa}$ / min, Figure 6A, until the adherence failure occurs between the adobe piece (two faces) and one of the concrete elements, see Figure 6B. A digital linear displacement meter was used to obtain a relation between force and deformation of the adobe piece.
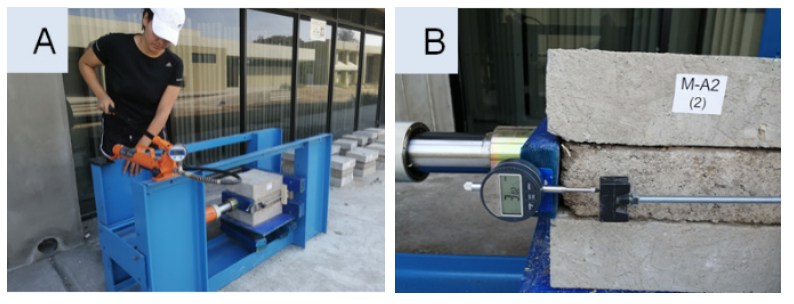

Figure 6. (A) Specimen test. (B) Adherence failure

\section{Result and Discussion}

\subsection{Soil Classification}

In the 6 adobe samples presented in this study, Table 6 , a medium to high plasticity is observed (Ip $>7$ ); samples A-5 and A-1 have a lower plastic index, sample A-2 stands out with the higher plastic index (Ip = 26.5), which is indicative of it being a mixture with a higher clay content.

Regarding linear contraction and expansion, sample A-1 presents a lower value, which makes the sample less vulnerable to volume changes in the presence of humidity, sample A-2 and A-3 showed the highest values, which makes them more unstable in their volumetric changes, classifying them as high plasticity due to having a higher percentage relation between the liquid limit and the plastic index.

Table 6. Proportion in volume

\begin{tabular}{|c|c|c|c|c|c|c|}
\hline Mix design & A-1 & A-2 & A-3 & A-4 & A-5 & A-6 \\
\hline \% is smaller than No. 4 sieve size & 0 & 0 & 0 & 17 & 15 & 13 \\
\hline \% is smaller than No. 40 sieve size & 75 & 72 & 33 & 43 & 42 & 42 \\
\hline \% is smaller than No. 200 sieve size & 25 & 28 & 67 & 40 & 43 & 45 \\
\hline $\begin{array}{c}\text { Dry weight of soil in densest } \\
\text { condition kg/m }\end{array}$ & 1178 & 1236 & 1218 & 1398 & 1312 & 1343 \\
\hline $\begin{array}{c}\text { Dry weight of soil in loosest } \\
\text { condition kg/m }\end{array}$ & 2059 & 2023 & 2089 & 2158 & 2073 & 2140 \\
\hline $\begin{array}{c}\text { Optimum water content \% } \\
\text { Liquid limit \% }\end{array}$ & 3.40 & 11.17 & 9.65 & 5.65 & 7.24 & 7.50 \\
\hline Plastic limit \% & 21.93 & 23.29 & 39.13 & 29.69 & 30.43 & 26.51 \\
\hline Plasticity index \% & 11.04 & 26.50 & 19.65 & 17.60 & 9.78 & 22.81 \\
\hline Linear contraction \% & 5.59 & 9.33 & 11.79 & 7.88 & 8.89 & 7.09 \\
\hline Expansion \% & 1.07 & 3.23 & 1.71 & 1.28 & 0 & 0.17 \\
\hline Classification SUSC & SC & SM & MH & SM & SM & SC \\
\hline Plasticity & M & H & H & M & M & M \\
\hline
\end{tabular}




\subsection{Cube Compression Test}

The resistance to direct compression of the adobe cubes was higher in pieces CA-2 (1.45 Mpa) and CA-1 (1.39 Mpa), which have the highest sand content and lowest plastic limit, Table 5, in the Table 7, the resistance efforts of the different test cubes can be observed, which correspond according to the number of the adobe samples identified with the letter A.

Table 7. Compressive strength

\begin{tabular}{|c|c|c|c|}
\hline Specimen & Failure load & \multicolumn{2}{|c|}{ Strength } \\
\hline No. & $\mathrm{Kg}$ & $\mathrm{Kg} / \mathrm{cm}^{2}$ & $\mathrm{MPa}$ \\
\hline CA-1 & 1257.32 & 14.15 & 1.39 \\
\hline CA-2 & 1301.15 & 14.82 & 1.45 \\
\hline CA-3 & 682.27 & 8.82 & 0.86 \\
\hline CA-4 & 910.11 & 10.67 & 1.05 \\
\hline CA-5 & 542.15 & 6.53 & 0.64 \\
\hline CA-6 & 749.78 & 9.26 & 0.91 \\
\hline & Average & 10.71 & 1.05 \\
\hline
\end{tabular}

\subsection{Adherence Test}

The resistance to adherence of the adobe samples with the concrete, had a similar behavior to each other, with similar stress values, Table 8 , mainly attributable to the same roughness characteristics of the contact surfaces, Figure 7, the specimen that showed greater resistance to adherence was MA-3, it should be noted that of the 36 specimens tested, in $28(78 \%)$ of them the failure was presented by one of the contact faces.

When relating the compression forces with the adherence forces, it can be seen as indicated in Figure 8, that there is no direct relation (non-linear) between the mentioned forces that can serve as a parameter for the calculation of one of them.

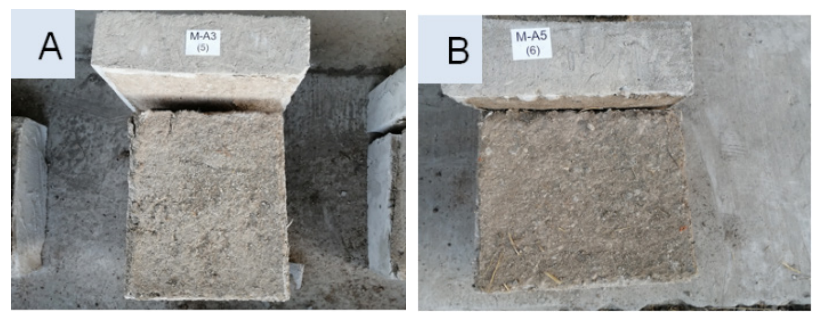

Figure 7. (A) Sample MA-3. (B) Sample MA-5

Table 8. Adherence test between adobe and concrete

\begin{tabular}{|c|c|c|c|c|c|c|}
\hline Sample & Piece & $\begin{array}{c}\text { Speed } \\
\text { load }\end{array}$ & $\begin{array}{c}\text { Failure } \\
\text { load }\end{array}$ & Disp* & \multicolumn{2}{|c|}{ Adherence } \\
\hline & & $\mathrm{Mpa} / \mathrm{min}$ & $\mathrm{kg}$ & $\mathrm{mm}$ & $\mathrm{kg} / \mathrm{cm}^{2}$ & $\mathrm{MPa}$ \\
\hline MA-1 & 6 & 0.93 & 627 & 2.16 & 0.413 & 0.040 \\
\hline MA-2 & 6 & 0.82 & 580 & 2.22 & 0.393 & 0.039 \\
\hline MA-3 & 6 & 0.92 & 614 & 3.65 & 0.432 & 0.042 \\
\hline MA-4 & 6 & 0.79 & 637 & 3.36 & 0.422 & 0.041 \\
\hline MA-5 & 6 & 0.84 & 626 & 2.59 & 0.420 & 0.041 \\
\hline MA-6 & 6 & 0.84 & 453 & 1.94 & 0.307 & 0.030 \\
\hline
\end{tabular}

*Disp $=$ Displacement

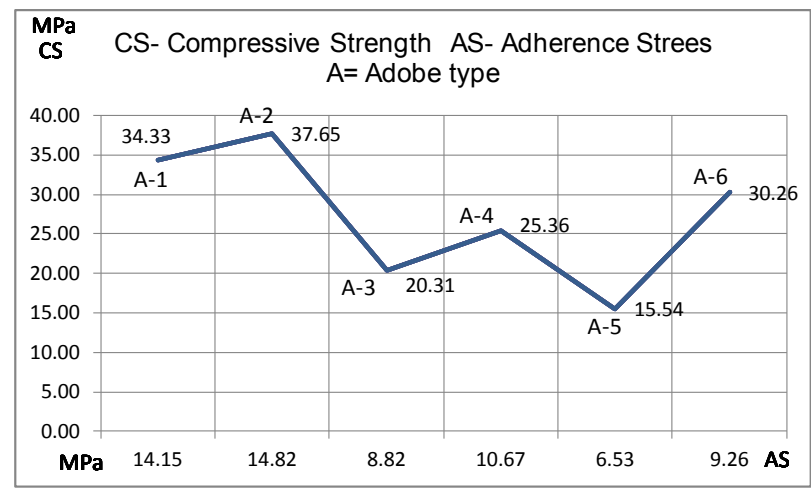

Figure 8. Compressive strength - Adherence stress, relation

\section{Conclusions}

The adherence between adobe and concrete elements is of vital importance for the good structural performance of constructions based on these materials. As there is no applicable standard for adherence between these two elements, a methodological process was proposed to serve as a starting point for conducting a trial test, where deeper data on the behavior between the two materials are obtained.

According to the mixtures tested for the manufacture of adobe in this study, it is appreciated that there is no appreciable difference in the internal bonding forces between the adobe and the concrete confining elements $(0.040 \mathrm{Mpa})$; the values obtained can be indirectly related to the adherence of the cement-sand based mortar with artisan brick, in the diagonal compression resistance test, where a minimum value of $0.20 \mathrm{MPa}$ is specified, when the failure is due to the mortar [16].

Considering that samples MA-1, MA-2 and MA-3 do not contain gravel, unlike samples MA-4, MA-5 and MA-6 with an average content of $15 \%$; the content of gravel in the indicated samples did not influence in an appreciable way in the friction force between the contact surfaces; the roughness of the contact faces of the 36 specimens was uniform.

It is recommended to carry out tests with a higher content of gravel in the mixture, and that it has greater exposure on the surface to achieve greater roughness, and serve as a transition of stresses between concrete and adobe.

It could also be seen that the compression and adherence stresses in the adobe are independent of each other, and cannot be taken to obtain a reference value for each one of the stresses, as occurs with concrete elements.

The tests were carried out with the specimens with a minimum drying of 30 days, exposure to the environment due to the presence of humidity can alter the plasticity of the pieces, and therefore experience changes in their volume that would affect adherence with the concrete.

This study only refers to the tested samples, for the manufacture of adobe, independent tests must be carried 
out for each type of mixture, in order to have accurate data of each place where confined constructions with concrete elements are manufactured or are made, due to the different degrees of plasticity of clays.

\section{Acknowledgments}

We are grateful to the Tijuana Technological Institute, Department of Earth Sciences, and the Autonomous University of Tamaulipas, Faculty of Architecture, Design and Urbanism, for the support for this research.

\section{REFERENCES}

[1] S. M. Alcocer. "Comportamiento sísmico de estructuras de mampostería”, una revisión. In Memorias del XI Congreso Nacional de Ingeniería Sísmica, Vol. 1, pp. 164-191, 1997. https://reconstruir.org.mx/wp-content/uploads/2017/11/4_c omportamiento_sismico_de_estructuras_de_mamposteria_u na_revision.pdf.

[2] A. San Bartolomé, E. Delgado, D. Quiun. "Seismic behavior of a two story model of confined adobe masonry". In Wael W. El-Dakhakhni, Robert G. Drysdale. Proceedings 11th Canadian Masonry Symposium. Toronto: McMaster University, 2009. https://www.researchgate.net/publication/ 291334764.

[3] F. Wu, H.T. Wang, L. Gang, J.Q. Jia, H. N. Li. "Seismic performance of traditional adobe masonry walls subjected to in-plane cyclic loading". Materials and Structures, Vol. 50, No. 1, pp. 69, 2017. DOI: 10.1617/s11527-016-0927-0.

[4] A. Preciado, A. Ramírez, J. Santos, O. Rodríguez. "Seismic vulnerability assessment and reduction at a territorial scale on masonry and adobe housing by rapid vulnerability indicators: The case of Tlajomulco, Mexico", 2020. DOI: 10.1016/j.ijdrr.2019.101425.

[5] R. Meli, O. Hernández. "Refuerzos de viviendas de adobe en zonas sísmicas”. Revista de Ingeniería Sísmica, No. 20, pp. 24-35. 1978. DOI: 10.18867/RIS.20.385.

[6] American Society for Testing and Materials. (2019). ASTM C270-19, "Standard Specification for Mortar for Unit Masonry". 2019. https://www.astm.org/Standards/C270.ht $\mathrm{m}$.

[7] G. Bernardo, E. Jeferson, "Determinación experimental de las prioridades de cohesión y ángulo de fricción de la mampostería de adobe, piedra y ladrillo en edificaciones históricas peruanas". pp. 9-28, 2016. http://tesis.pucp.edu.p e/repositorio/handle/20.500.12404/7289.

[8] R. D. Pasquantonio, G. A. Parsekian, F. S. Fonseca, N. G. Shrive. "Experimental and numerical characterization of the interface between concrete masonry block and mortar". Revista Ibracon de Estruturas e Materiais, Vol. 13, No. 3, pp. 578-592, 2020. DOI: 10.1590/s1983-41952020000300008.

[9] NTE, E. 080. Adobe. ININVI: “Adobe construction. Technical Standard for adobe building". Special disposition for seismic-resistant adobe building. Lima, Peru, 2017. https://www.getty.edu/conservation/publications resources/ pdf_publications/pdf/testing_materials_spanish.pdf.

[10] American Society for Testing and Materials. ASTM D2487-17. "Classification of Soils for Engineering Purposes Unified Soil Classification System”. 2017. https://www.ast m.org/Standards/D2487.htm

[11] Organismo Nacional de Normalización y Certificación de la Construcción y Edificación, S.C., NMX-C-493-ONNCE-20 18. Industria de la Construcción Geotecnia, "Límites de Consistencia de Suelos". Método de Ensayo", México, 2018.http://www.dof.gob.mx/nota detalle.php? codigo $=555$ $2886 \&$ fecha $=14 / 03 / 2019$.

[12] American Society for Testing and Materials. ASTM D427-04. "Test Method for Shrinkage Factors of Soils by the Mercury Method". 2004. https://www.astm.org/Standar ds/D427.htm.

[13] Organismo Nacional de Normalización y Certificación de la Construcción y Edificación, S.C. NMX-C-522-ONNCCE-2 016. Industria de la construcción, Geotecnia, Materiales térreos. "Determinación del valor soporte de California de suelos y expansión en laboratorio". Método de ensayo, México, 2016. https://www.dof.gob.mx/nota_detalle.php?c odigo $=5461708 \&$ fecha $=22 / 11 / 2016$.

[14] Amaya-Ruiz, I., Fuentes-Perez, C. A., Arista-Gonzalez, G. J., Sanchez-Medrano, M. T., Kulich, E. F. I., \& Suarez-Dominguez, E. J. (2020). Estimation of the effect of the composition of the wall on the comfort of a building. International Journal of Advanced Trends in Computer Science and Engineering, 9(3). DOI: 10.30534/ijatcse/2020/ 43932020

[15] BS EN 1052-3:2002, "Methods of test for masonry". Determination of initial shear strength. 2002. http://www.ydylstandards.org.cn/static/down/pdf/EN\%2010 52-3-2002 en.pdf.

[16] NTC-DCEM (2020). Normas técnicas complementarias para diseño y construcción de estructuras de mampostería; Gaceta oficial de la Ciudad de Mexico, pp. 54-55, 2020. https://www.smie.org.mx/archivos/informacion-tecnica/nor mas-tecnicas-complementarias/normas-tecnicas-compleme ntarias-diseno-construccion-estructuras-mamposteria-19-oc tubre-2020.pdf. 